\title{
Polymerase chain reaction for screening clinical isolates of corynebacteria for the production of diphtheria toxin
}

\author{
M J Pallen, A J Hay, L H Puckey, A Efstratiou
}

\begin{abstract}
Aims-To assess the performance of the polymerase chain reaction (PCR) when used to screen rapidly large numbers of corynebacteria for toxin production; and to determine the incidence of false positive PCR results with non-toxigenic Corynebacterium diphtheriae isolates. Methods-Eighty seven recent British isolates of corynebacteria were assayed by PCR. All isolates were assayed from both blood and tellurite agar within a five day period. Thirty three non-toxigenic isolates of $C$ diphtheriae from six countries were also tested by PCR and by the Elek immunodiffusion assay.

Results-There was complete concordance between the results of PCR and traditional methods on the recent British isolates, with one exception: an Elek positive "C ulcerans" isolate, which was PCR positive from tellurite but not from blood agar. One of the thirty three (3\%) nontoxigenic isolates of $C$ diphtheriae was PCR positive.

Conclusions-These results suggest that PCR compares favourably with traditional methods for the detection of toxigenic corynebacteria and that it represents a powerful new tool in the diagnosis of an old disease.
\end{abstract}

(F Clin Pathol 1994;47:353-356)

Diphtheria typically presents as a severe pharyngitis with tough pharyngeal membrane, which may extend to the larynx and trachea, causing suffocation. ${ }^{1}$ Diphtheria toxin is absorbed into the circulation and can cause myocardial and neurological damage. ${ }^{1}$ Vaccination substantially reduces the risk of developing diphtheria but prevents neither asymptomatic carriage of toxigenic strains of $C$ diphtheriae nor the pharyngitis and invasive infections caused by non-toxigenic strains. ${ }^{2}$

Although diphtheria is now rare in the West, there have been numerous outbreaks in Europe and North America in the past 30 years. ${ }^{3}$ Serological surveys have shown that many adults and children in the industrialised world are not protected against diphtheria, ${ }^{34}$ and a recent fatality in the USA shows how diphtheria may still strike unprotected individuals with deadly ferocity. ${ }^{4}$ Diphtheria is endemic in many developing countries and an epidemic of the disease currently rages in parts of the former Soviet Union. ${ }^{5-7}$ Reports from Finland of diphtheria in recent visitors to Russia demonstrate the constant risk of importation of toxigenic strains. ${ }^{7}$

As very few doctors in Europe or North America have seen diphtheria, all but the most obvious cases may be missed on clinical diagnosis. ${ }^{7}$ Many microbiology laboratories routinely screen all throat swabs for the presence of toxigenic $C$ diphtheriae. ${ }^{8}$ However, both harmless commensals ("diphtheroids") and non-toxigenic isolates of $C$ diphtheriae are often isolated from throat swabs, causing anxiety among laboratory staff, clinicians, and public health officials until they have been distinguished from toxigenic $C$ diphtheriae. This is often a slow and difficult process that can sometimes take as long as seven days. ${ }^{9}$

Suspect organisms are usually assayed for toxin production using the Elek immunodiffusion assay, with virulence confirmed in guinea-pigs when animal facilities are available. ${ }^{10}$ The Elek test is both slow (typically taking 18 to 48 hours to produce a result) and technically demanding - in a national quality assessment trial nearly a third of British laboratories produced erroneous results when given a week or more to assay just four strains of $C$ diphtheriae. ${ }^{11}$ Guinea-pig testing is not suitable as a first-line assay for toxigenicity, as it takes even longer than the Elek test and is undesirable on other grounds (cost and animal welfare).

In a preliminary study at St Bartholomew's Hospital, the polymerase chain reaction (PCR) showed promise as an alternative technique for toxigenicity testing of $C$ diphtheriae. ${ }^{12}$ The potential of the technique was confirmed by a subsequent small scale study by some Swiss workers. ${ }^{13}$ Here, we report two larger studies in which we evaluate the potential of PCR to detect the production of diphtheria toxin in clinical isolates: a blinded survey of 87 clinical isolates of corynebacteria sent to the Diphtheria Reference Unit (DRU) to see how PCR performed when large numbers of isolates were screened quickly; and a survey of 33 Elek negative isolates of $C$ diphtheriae to find out how often non-toxigenic isolates gave false positive results in our PCR assay.

\section{Methods}

RECENT UK CLINICAL ISOLATES

Eighty seven corynebacterial isolates that had been sent by UK laboratories to the Diphtheria Reference Unit (DRU) of the Respiratory and Systemic Infection 
Table 1 Identity of 87 UK isolates surveyed by PCR

\begin{tabular}{lc}
\hline Toxigenic isolates: & $N=$ \\
Cdiphtheriae var gravis & 2 \\
C diphtheriae var mitis & 15 \\
"C ulcerans" & 2 \\
Total & 19 \\
Non-toxigenic isolates: & \\
Atypical C diphtheriae var gravis & 23 \\
C diphtheriae var mitis & 3 \\
C diphtheriae var belfanti & 9 \\
C pseudotuberculosis & 2 \\
C pseudodiphtheriticum & 4 \\
Cxerosis & 6 \\
C minitissimum & 1 \\
C urealyticum & 6 \\
C jeikeeium & 6 \\
"Diphtheroids" & 8 \\
Total & 68 \\
\hline
\end{tabular}

*The atypical non-toxigenic biotype currently prevalent in the UK. ${ }^{2}$ For isolates from species other than $C$ diphtheriae, " $C$ ulcerans" and $C$ pseudotuberculosis, the negative Elek status was ulcerans" and $C$ pseudotuberculosis, the
usually assumed rather than proved.

Laboratory at the Central Public Health Laboratory in 1989 and 1990 were included in the study (table 1). Routine identification of these isolates and toxigenicity testing by the Elek immunodiffusion test were carried out in the DRU. The isolates were then sent to $\mathrm{St}$ Bartholomew's Hospital, where they were tested by PCR, without prior knowledge of their identity or toxigenicity.

\section{NON-TOXIGENIC ISOLATES FROM THE CARNE COLLECTION}

Thirty three isolates of $C$ diphtheriae were selected from the Carne collection. This collection contains corynebacterial isolates assembled over many years by HR Carne of Cambridge and is now held by the National Collection of Type Cultures. All the selected isolates were listed as "non-toxigenic". These were tested at St Bartholomew's Hospital for toxin production using the Elek test and then assayed by PCR.

\section{PLAN OF INVESTIGATIONS}

The 87 recent clinical isolates were subcultured on to blood agar and on to Hoyle's tellurite blood agar and incubated for 24-48 hours at $37^{\circ} \mathrm{C}$. Each isolate was assayed twice by PCR, once from blood agar and once from tellurite agar. Isolates were tested by one individual (MJP) on four successive mornings, in four batches of 40 to 50 isolates. A positive control strain (NCTC 10648) was included in each PCR run. Reactions giving uncertain results were retested on the fifth morning. The 33 strains from the Carne collection were assayed in a single PCR run, again testing each strain twice, from blood and tellurite agar.

\section{POLYMERASE CHAIN REACTION}

The PCR mixture was set up as a master mix: $10 \mathrm{mM}$ TRIS-HCl, $\mathrm{pH} 8 \cdot 3 ; 50 \mathrm{mM} \mathrm{KCl} ; 1 \cdot 5$ $\mathrm{mM} \mathrm{MgCl} ; 200 \mathrm{mM}$ each dNTP; 2.5 units AmpliTaq polymerase (Perkin-Elmer); 60 pmol of each primer per $100 \mu \mathrm{l}$; control template added as below. The reaction mix was then aliquotted into $25 \mu \mathrm{l}$ volumes in $0.5 \mathrm{ml}$ polypropylene tubes. A loopful of each isolate was inoculated into $1 \mathrm{ml}$ of distilled water in a
$1.5 \mathrm{ml}$ polypropylene tube, boiled for $10 \mathrm{~min}$ utes, then centrifuged for one minute. Supernatant fluid $(1 \mu \mathrm{l})$ was added to each $25 \mu$ l PCR mixture. The two primers used were based on published diphtheria toxin gene sequences (5'-ATCCACTTTTAGTGCGAGAACCTTCGTCA-3' and 5'GAAAACTTTTCTTCGTACCACGGGAC TAA-3' $)^{14-16}$ and amplified a 248 base pair fragment of the toxin gene from positive samples. After an initial denaturation step $\left(96^{\circ} \mathrm{C}\right.$ for two minutes 30 amplification cycles $\left(94^{\circ} \mathrm{C}\right.$ for 15 seconds, $50^{\circ} \mathrm{C}$ for 15 seconds, $72^{\circ} \mathrm{C}$ for 30 seconds were performed under thermocouple control on a Hybaid Thermal Reactor, with a final 10 minutes extension step at $72^{\circ} \mathrm{C}$.

\section{INTERNAL PCR CONTROL AND PRODUCT DETECTION}

We have already described a rapid method for detecting false negative PCR results due to reaction failure. ${ }^{17}$ In this method an artificial control template is added to each reaction. Although the control template contains an internal 42 base pair deletion, which allows it to be distinguished from the natural PCR product by electrophoretic mobility, it is none the less amplified by the same primer pair as the natural template. The control template is amplified in all successful negative reactions and in some of the positive reactions. Curiously, for reasons that are unclear, the natural product is often synthesised in preference to the artificial product in positive reactions. ${ }^{17}$

In the assays described here a completed PCR containing the control fragment was diluted a million-fold in water and $1 \mu \mathrm{l}$ of this dilution was included in each $100 \mu \mathrm{l}$ of the PCR mix. The presence of a 206 base pair band in the negative reactions showed that the master mix had been set up correctly and that there were no substances inhibitory to the PCR present in samples.

Completed reactions were subjected to rapid electrophoresis on a $2 \%$ agarose gel containing ethidium bromide and visualised on an ultraviolet light transilluminator. Samples were run just long enough (typically 20 to 30 minutes) to differentiate positive reactions containing a 248 base pair band (with or without the control product) from negative reactions containing only the 206 base pair control product. Reactions were judged to have failed if no product was obtained.

\section{Results}

RECENT UK CLINICAL ISOLATES

All but two of the $87 \mathrm{UK}$ isolates had been tentatively identified as either toxigenic or non-toxigenic by the end of the fourth day, basing the result on at least one successful reaction per isolate (typical data are shown in the figure). Only sixteen of 180 reactions were judged to have failed or given weak results that required confirmation on the fifth day. At the completion of the survey, 18 of the 87 isolates were judged to be unequivocally positive 


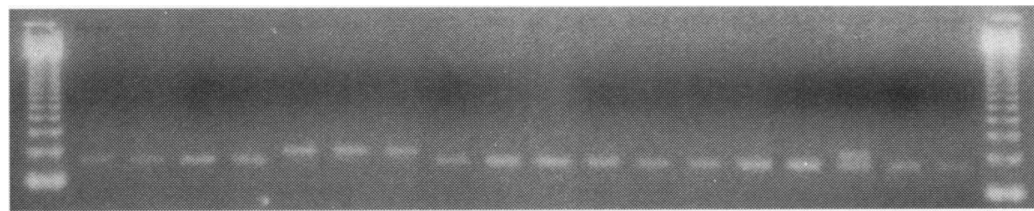

M $\uparrow \uparrow \uparrow$

$\uparrow$

M

Typical results on 18 of the UK isolates. The control fragment (206 base pairs) is seen in all 14 negative reactions. The larger natural product ( 248 base pairs) is seen, with or without the control fragment, in the four positive reactions (arrowed). The lanes marked $M$ contain molecular weight markers (100 base pairs ladder, Gibco BRL, Paisley, Scotland)

by PCR; one gave inconsistent results; and the rest were PCR negative.

The PCR results were conveyed to the DRU, who then released information on the identity and toxigenicity of all isolates (table 1). There was complete concordance between the results of the PCR and conventional tests for all but one of the isolates. The only discrepant result came from an Elek positive isolate of $C$ ulcerans, which was PCR positive from tellurite agar but not from blood agar. This result was reproducible and probably reflected poorer lysis of the isolate after growth on blood agar.

\section{CARNE COLLECTION ISOLATES}

Thirty two of the 33 Elek negative Carne strains were negative on PCR testing. One isolate-from Trinidad-was reproducibly positive on PCR, but negative on Elek testing, both at St Bartholomew's Hospital and in the DRU (table 2).

\section{Discussion}

The survey of the UK isolates reported here shows that PCR works well even when used to screen large numbers of isolates in a short period of time-all 87 isolates were

Table 2 PCR and Elek results on strains from the Carne Collection

\begin{tabular}{|c|c|c|c|c|}
\hline NCTC No & Biotype & $\begin{array}{l}\text { Country of } \\
\text { origin }\end{array}$ & Elek result & $P C R$ result \\
\hline $\begin{array}{l}\text { A221/84 } \\
\text { A222/84 } \\
\text { A223/84 } \\
\text { A224/84 } \\
\text { A225/84 } \\
\text { A401/84 } \\
\text { A402/84 } \\
\text { A412/84 } \\
\text { A413/84 } \\
\text { A414/84 } \\
\text { A416/84 } \\
\text { A443/84 } \\
\text { A226/84 } \\
\text { A202/84 } \\
\text { A231/84 } \\
\text { A417/84 } \\
\text { A418/84 } \\
\text { A421/84 } \\
\text { A422/84 } \\
\text { A400/84 } \\
\text { A403/84 } \\
\text { A406/84 } \\
\text { A436/84 } \\
\text { A437/84 } \\
\text { A438/84 } \\
\text { A439/84 } \\
\text { A448/84 } \\
\text { A449/84 } \\
\text { A450/84 } \\
\text { A452/84 } \\
\text { A201/84 } \\
\text { A218/84 } \\
\text { A219/84 }\end{array}$ & $\begin{array}{l}\text { mitis } \\
\text { mitis } \\
\text { mitis } \\
\text { mitis } \\
\text { mitis } \\
\text { gravis } \\
\text { gravis } \\
\text { Unknown } \\
\text { Unknown } \\
\text { Unknown } \\
\text { mitis } \\
\text { gravis } \\
\text { mitis } \\
\text { mitis } \\
\text { Unknown } \\
\text { Unknown } \\
\text { Unknown } \\
\text { Unknown } \\
\text { Unknown } \\
\text { gravis } \\
\text { gravis } \\
\text { gravis } \\
\text { gravis } \\
\text { gravis } \\
\text { gravis } \\
\text { gravis } \\
\text { mitis } \\
\text { mitis } \\
\text { mitis } \\
\text { mitis } \\
\text { mitis } \\
\text { mitis } \\
\text { mitis }\end{array}$ & $\begin{array}{l}\text { Canada } \\
\text { Canada } \\
\text { Canada } \\
\text { Canada } \\
\text { Canada } \\
\text { Canada } \\
\text { Canada } \\
\text { Canada } \\
\text { Canada } \\
\text { Canada } \\
\text { Canada } \\
\text { Canada } \\
\text { Columbia } \\
\text { Romania } \\
\text { Trinidad } \\
\text { Trinidad } \\
\text { Trinidad } \\
\text { Trinidad } \\
\text { Trinidad } \\
\text { UK } \\
\text { UK } \\
\text { UK } \\
\text { UK } \\
\text { UK } \\
\text { UK } \\
\text { UK } \\
\text { UK } \\
\text { UK } \\
\text { UK } \\
\text { UK } \\
\text { USA } \\
\text { USA } \\
\text { USA }\end{array}$ & $\begin{array}{l}\text { Negative } \\
\text { Negative } \\
\text { Negative } \\
\text { Negative } \\
\text { Negative } \\
\text { Negative } \\
\text { Negative } \\
\text { Negative } \\
\text { Negative } \\
\text { Negative } \\
\text { Negative } \\
\text { Negative } \\
\text { Negative } \\
\text { Negative } \\
\text { Negative } \\
\text { Negative } \\
\text { Negative } \\
\text { Negative } \\
\text { Negative } \\
\text { Negative } \\
\text { Negative } \\
\text { Negative } \\
\text { Negative } \\
\text { Negative } \\
\text { Negative } \\
\text { Negative } \\
\text { Negative } \\
\text { Negative } \\
\text { Negative } \\
\text { Negative } \\
\text { Negative } \\
\text { Negative } \\
\text { Negative }\end{array}$ & $\begin{array}{l}\text { Negative } \\
\text { Negative } \\
\text { Negative } \\
\text { Negative } \\
\text { Negative } \\
\text { Negative } \\
\text { Negative } \\
\text { Negative } \\
\text { Negative } \\
\text { Negative } \\
\text { Negative } \\
\text { Negative } \\
\text { Negative } \\
\text { Negative } \\
\text { Negative } \\
\text { Positive } \\
\text { Negative } \\
\text { Negative } \\
\text { Negative } \\
\text { Negative } \\
\text { Negative } \\
\text { Negative } \\
\text { Negative } \\
\text { Negative } \\
\text { Negative } \\
\text { Negative } \\
\text { Negative } \\
\text { Negative } \\
\text { Negative } \\
\text { Negative } \\
\text { Negative } \\
\text { Negative } \\
\text { Negative }\end{array}$ \\
\hline
\end{tabular}

tested within five working days. Although one " $C$ ulcerans" isolate gave discrepant results when assayed from blood and tellurite agar, this finding is less worrying than if it had occurred with a $C$ diphtheriae isolate, as " $C$ ulcerans" does not seem to have the same potential to cause epidemic diphtheria as $C$ diphtheriae. None the less it is probably prudent to carry out PCR on colonies from tellurite agar rather than from blood agar if using a simple boiling protocol for sample preparation. Improved results may be possible if a more sophisticated DNA extraction protocol is used-Lucchini, Gruner, and Altwegg ${ }^{13}$ reported better results with a classic mini-prep technique than with a quick boiling procedure-but such protocols can add several hours to the entire assay, making it less suitable as a rapid test.

Only one of 33 (3\%) non-toxigenic isolates from the Carne collection gave a product on PCR. This is an acceptable false positive rate, especially when compared with the poor performance in time and accuracy of the Elek test (26 of 175 (15\%) laboratories reported a nontoxigenic strain of $C$ diphtheriae to be Elek positive in the national quality assessment trial mentioned above). ${ }^{11}$ In practice, the overall false positive rate for the PCR assay is likely to be lower than this $(0 \%$ in our survey of British isolates), as most suspicious corynebacterial isolates that one might want to screen in the clinical laboratory are not even isolates of $C$ diphtheriae but belong to other species or genera. The low proportion of non-toxigenic isolates of $C$ diphtheriae found to carry toxin gene sequences in the Carne collection isolates contrasts sharply with the findings of Groman and others, ${ }^{18}$ who, testing US isolates with gene probes, found that 14 of 43 non-toxigenic isolates carried at least part of the toxin gene. The discrepancy is almost certainly because the set of isolates studied by Groman and others was biased by inclusion of a large number of isolates from one particular state, South Dakota, where a single non-toxigenic clone was highly prevalent. ${ }^{18}$ As the Carne isolates came from six countries on three continents, the results from these isolates are more likely to reflect the global picture than those from Groman's survey. Given that non-toxigenic isolates of $C$ diphtheriae carrying the toxin gene are quite rare in global terms, it is unlikely that such isolates will compromise the utility of the PCR assay except, perhaps, in certain defined localities. Work is underway to determine the mutations responsible for the loss of toxigenicity in Groman's isolates and in the anomalous PCR positive isolate from the Carne collectionthis may lead to a more accurate second generation PCR assay and will shed light on the molecular epidemiology of diphtheria toxin production.

In conclusion, PCR represents a powerful modern tool for the diagnosis of an old disease, with several advantages over the traditional methods used to determine the toxigenicity of corynebacterial isolates: PCR is quicker, works on mixed cultures, ${ }^{12}$ works on 
cultures from inhibitory media, and does not require biological reagents that are difficult to standardise. The technique will prove even more useful if non-electrophoretic detection systems can be devised and if, with improved lysis protocols, it can be adapted to detect the diphtheria toxin gene directly in clinical specimens-for example, throat swabs.

This work was supported by a Gerhard Domagk award from Bayer and the British Society for the Study of Infection.

1 Christie AB. Diphtheria. In: Infectious Diseases: Epidemiology and clinical practice. Vol 2. London: Churchill Livingstone, 1987:1 183-209.

2 Efstratiou A, George RC, Begg NT. Non-toxigenic Corynebacterium diphtheriae var gravis in England. Corynebacterium diphther

3 Pallen MJ. Detection and characterisation of diphtheria toxin genes and insertion sequences by PCR and othe molecular techniques. [MD Thesis.] University of London, 1993:35-48.

4 Farizo KM, Strebel PM, Chen RT, Kimbler A, Cleary TJ, Cochi SL. Fatal respiratory disease due to Corynebacterium diphtheriae: case report and review of guidelines for management, investigation and control. Clin Infect Dis 1993;16:59-68.

5 WHO. Expanded Programme on Immunization. Outbreak of diphtheria. USSR. Weekly Epidemiological Record of diphtheria.

6 Rich V. Soviet Union: Diphtheria tightens its grip. Lancet 1991;338:1004.

7 Lumio J, Jahkola M, Vuento R, Haikala O, Eskola J. Diphtheria after visit to Russia. Lancet 1993;342:53-4.
8 Wilson AP, Ridgway GL, Gruneberg RN, Efstratiou A, Colman G, Cookson B. Routine screening for Corynebacterium diphtheriae. Lancet 1990;336:1199.

9 Zizmor J, Deluty S. Diphtherial stomatitis: a complication of immunosuppressive therapy. Arch Dermatol 1978 114:138-41.

10 Brooks R, Joynson DH. ACP Broadsheet No 125 Bacteriological diagnosis of diphtheria. F Clin Pathol 1990 43:576-80.

11 Snell JJS, Demello JV, Gardner PS, Kwantes W, Brooks R Detection of toxin production by Corynebacterium diphtheriae: results of a trial organised as part of the United Kingdom National External Microbiological United Kingdom National External Microbiological
Quality Assessment Scheme. f Clin Pathol 1984;37:796-9. 12 Pallen MJ. Rapid screening for toxigenic Corynebacterium
diphtheriae by the polymerase chain reaction. $\exists$ Clin Pathol 1991;44:1025-6.

13 Lucchini ML, Gruner E, Altwegg M. Rapid detection of diphtheria toxin by the polymerase chain reaction. Med Microbiol Lett 1992;1:276-83.

14 Greenfield L, Bjorn MJ, Horn G, Fong D, Buck GA Collier RJ, et al. Nucleotide sequence of the structural gene for diphtheria toxin carried by corynebacteriophage gene for diphtheria toxin carried by corynebacte
B. Proc Natl Acad Sci USA 1983;80:6853-7.

15 Ratti G, Rappuoli R, Giannini G. The complete nucleotide sequence of the coding for diphtheria toxin in the corynephage omega (tox + ) genome. Nucleic Acids Res 1983;11:6589-95.

16 Kaczorek M, Delpeyroux F, Chenciner N, Streeck RE Murphy JR, Boquet $P$, et al. Nucleotide sequence and expression of the diphtheria tox228 gene in Escherichia coli. Science 1983;221:855-8.

17 Pallen MJ, Puckey LH, Wren BW. A rapid simple method for detecting PCR failure. PCR Methods Appl 1992; 2:91-2.

18 Groman N, Cianciotto N, Bjorn M, Rabin M. Detection and expression of DNA homologous to the tox gene in non-toxigenic isolates of Corynebacterium diphtheriae. Infect Immun 1983;42:48-56. 